\title{
Sözel İmgelerin Müzik Öğretmeni Adaylarının Şarkı Söyleme Becerileri Üzerindeki Etkisi
}

\author{
The Influence of Verbal Images on Music Teacher Candidates' Singing Skills \\ Tülay Ekici \\ Öğr. Gör. Dr., Dokuz Eylül Üniversitesi Buca Eğitim Fakültesi Güzel Sanatlar Eğitimi Bölümü Müzik Eğitimi Anabilim Dalı \\ email: tulay.ekici@deu.edu.tr (DORCID ID: https://orcid.org/0000-0001-9587-7849
}

iThenticate“ Bu makale bilimsel etik ve kurallara uygun hazırlanmıș ve intihal incelemesinden geçirilmiștir.

Atıf (APA 6)/To cite this article

Ekici, T. (2020). Sözel imgelerin müzik öğretmeni adaylarının şarkı söyleme becerileri üzerindeki etkisi. Atatürk Üniversitesi Güzel Sanatlar Enstitüsü Dergisi, 26(Müzik Özel Sayıs1), 423-437. doi: https://doi.org/10.35247/ataunigsed.548415

Makale Gönderim Tarihi/Received: 02/04/2019

Makale Kabul Tarihi/Accepted: 06/10/2019

Makale Yayın Tarihi/Published: 25/03/2020

Research Article / Araştırma Makalesi

$\ddot{O} z$

Günümüz bilgi çağında, toplumların temel hedeflerinden biri de bilim, teknoloji ve sanat alanlarında nitelikli ve yaratıcı bireylerin yetişmesidir. Bilim ve teknoloji yanında sanat eğitimi, bireylerin özellikle yaratıcı yönünün ve duyarlılığının gelişmesine katkı sağlaması nedeniyle önemli bir işleve sahiptir. Sanatın bir kolu olan müzik eğitimi kapsamında yer alan ses eğitiminin genel amacı, konuşma ve şarkı söylemede, öğrencilerin seslerini en iyi şekilde kullanmalarını sağlamaktır. Bu amacın gerçekleştirilmesi, onlara sunulacak nitelikli eğitim anlayışı ile sağlanabilir. Dolayısıyla eğitim sürecinde kullanılacak etkili ve verimli öğretim yöntemlerinin seçilmesi önemlidir. Ses eğitiminde bir yöntem olarak sözel imgelerin kullanılması ile şarkı söyleme becerilerinin geliştirilmesi, öğrencilere uzun yıllar sağlıklı bir şekilde seslerini kullanma ve şarkı söyleme olanağı sağlayacaktır. Ayrıca öğretmen-öğrenci iletișimi ve eğitim süreci de daha sağlıklı, verimli ve etkili olacaktır. Bu doğrultuda bu çalışmanın amacı, sözel imgelerin müzik öğretmeni adaylarının șarkı söyleme becerileri üzerindeki etkisini arastırmaktır. Araştırma, 2018-2019 öğretim y1lı güz döneminde, Dokuz Eylül Üniversitesi Buca Eğitim Fakültesi Müzik Eğitimi Anabilim Dalı'nda 1. sınıfta öğrenim gören 10 öğrenci ile yürütülmüştür. Öntest-sontest kontrol gruplu modelin kullanıldığı araştırmada, öğrencilerin öğretim yılı başındaki șark1 söyleme performansları ile dönem sonundaki performansları, biri araştırmacı olmak üzere, 2 ses eğitmeni tarafindan değerlendirilmiștir. Arastırmada, deney öncesi ve deney sonrası değerlendirme sonuçları arasında deney grubunun lehine anlamlı düzeyde gelişme olduğu saptanmıştır

Anahtar kelimeler: Sözel İmge, Müzik Öğretmeni, Sark1 Söyleme Becerisi

\begin{abstract}
In today's information age, one of the main goals of the societies is to raise qualified and creative individuals in the fields of science, technology and art. Besides science and technology, art education has an important function because it contributes to the development of individuals' creative direction and sensitivity. The main purpose of the voice education within the scope of music education which is a branch of art is to ensure that the students use their voices in the best way in speaking and singing. Therefore, it is important to select effective and efficient teaching methods to be used in the training process. Through the use of verbal images as a method in voice education, the development of singing skills will enable students to use their voices and sing in a healthy way for many years. In addition, teacher-student communication and education process will be more healthy, efficient and effective. In this context, the purpose of this study is to investigate the effects of verbal imagery on music teacher candidates' singing skills. This study is conducted in the fall semester of 2018-2019 academic year with ten prospective teachers attending in Music Education Department at Buca Faculty of Education at Dokuz Eylul University. Both at the beginning of the academic year and at the end of the period, students' singing performances were evaluated by the two voice instructors one of whom is researcher in the study in which pretest post-test control group model is used. In the study, it was determined significantly progress in favor of experimental group between the results of evaluation pre-test post-test.
\end{abstract}

Keywords: Verbal İmagery, Music Teacher, Singing Skill

\section{Giriş}

Günümüzde bilim ve teknoloji alanında yaşanan hızlı değişme ve gelişmeler, çağın gereklerine uygun şekilde, nitelikli ve yaratıcı bireylerin yetişmesini sağlayacak nitelikli eğitim anlayışını ve uygulamalarını da zorunlu hale getirmiştir. Her toplumun kendi kültürel yapısına uygun bir eğitim sistemi olsa da yirmi birinci yüzyılda toplumların bilim, teknoloji ve sanat alanlarında çağdaş düzeyde ve uluslararası platformda varlığını sürdürmesi, nitelikli ve yaratıcı eğitim anlayışına bağlıdır

Eğitim genel olarak, bireyin sosyal hayata ve çağa uyum sağlayabilmesi için davranışlarının istenilen yönde değişmesi ve geliştirilmesi süreci olarak tanımlanabilir. Eğitimin bir boyutunu oluşturan sanat eğitimi ve sanat yoluyla eğitim, bireyin özellikle yaratıcı yönünü geliştirmesi nedeniyle önemlidir. Herbert Read (1963), sanat yoluyla eğitim kuramını şöyle belirtmektedir:

Bir insanda gelişme, ancak görülebilir ya da işitilebilir simgelerin anlatımı yoluyla olur. Eğitim böylece ve bir anlamda bu anlatım biçimlerinin geliştirilmesidir. Bu da çocuğa ve yetişkine nasıl devinimler yapacağının, imgeler, sesler, araçlar ve kullanım nesneleri yaratacağının öğretilmesidir. Bir insan eğer bütün bunları yapabiliyorsa, işte o insan tam olarak eğitilmiş insandır (aktaran Kırışoğlu, 2005, s. 25). 
San'a (1983) göre, H. Daucher ve R. Seitz'in sanat eğitiminde imgesel düşünmenin gerekliliği ile ilgili görüşleri önemlidir. Daucher, düşünme ile görme arasındaki sıkı ilişkinin, değişik düşünme biçimlerine yol açtığını, çocuğu yetişkinden, usçuluk öncesi dönemleri zamanımızdan ayıranın da bu düşünme biçimleri arasındaki ayrım olduğunu söylemektedir. Böylece imgesel düşünmeyle kavramsal düşünme ya da sanatsal görme ile ussallaştırılmış görme karşıt kavramlarını ortaya koyarak, irdelemesini bu kavram çiftleri üzerinde yoğunlaştırmaktadır. H. Daucher ve R. Seitz'in birlikte yazdıkları 'Biçimleyici Sanatların Didaktiği'nde, ussal kavramının soyuttan oluştuğu, imgesel, ussal öncesi kavramın da algıdan oluştuğu benimsenir. İmgesel deyince, geniş bir bildirişim alanı anlaşılır. Ussal ya da bilimsel düşünme çizgiseldir, tekniktir, saf kavramlar kullanır, "erken düşünme biçimi” olarak nitelenen imgesel düşünme ise, dal budak sarmış gibidir, resimsel tasarımlarla, imgelerle düşünür (aktaran Oskay, 2004, s. 29).

Bu bağlamda, imge ve imgelem kavramlarını ele almak ve tanımlamak doğru olacaktır. Eski Türkçe'de işaret anlamına gelen "im" sözcügünden türemiş olan imge, sözlük anlamı olarak birkaç şekilde tanımlanmıştır: 1 . Zihinde tasarlanan ve gerçekleşmesi özlenen şey, hayal, hülya. 2. Duyu organlarının dıștan algıladığı bir nesnenin bilince yansıyan benzeri, hayal, imaj. 3. Duyularla algılanan bir uyaran söz konusu olmaksızın bilinçte beliren nesne ve olaylar, hayal, imaj ("TDK", t.y.).

Keser'e (2005) göre; imge, gerçekliğin birebir kopyası değil, zihinsel süreçlerle yeniden kurulmuş biçimidir ve bu nedenle yeni bir şeyi temsil eder (aktaran Işıldak, 2008, s. 65). Berger’e (1995) göre; “imge, ilk kez ortaya çıktığı yerden ve zamandan (birkaç dakika ya da birkaç yüzyıl için) kopmuş ve saklanmış bir görünüm ya da görünümler düzenidir." Buna göre imge, yeniden yaratılmış ya da yeniden üretilmiş bir görünümdür. Timuçin (2000), imgeyi tanımlarken, dış kaynaklı olanları duyumsal imge, imgelemin ürünü olan imgeleri ise zihinsel imge olarak ikiye ayırır: "İmge, önce dış dünya nesnelerinin algıyla gerçekleşen basit bir sunumudur. ...Kavramsal düşünmenin temelini oluşturur... İkinci olarak imge, imgelemin doğrudan doğruya yaratısı olarak vardır. İmgelem, herhangi bir gereksinimle ya da boş bir edimle bir şey tasarladığında imge oluşmuş olur.” Zihinsel imgeler oluşturabilmek için duyumsal imgelere ihtiyacımız vardır. Bizde duyumsal imgesi olmayan bir şeyi zihnimizde tasarlayamayız (aktaran Oskay, 2004, s. 6-7).

İmgelerle düşünme, insanların kullandığı en eski zihinsel düşünce süreçlerindendir. Düşlerin, mantığın, dinin ve tüm gerçek gözlemlerin kaynağı olarak düşünülebilir. İlkellerden başlayarak, çok geniş bir zaman dilimine kadar insanlar imgelerle düşünmüşlerdir. Geçmişten günümüze felsefi düşünceler, bilimsel gelişmeler ve özellikle psikolojinin bir bilim olarak var olmasıyla birlikte, imge kavramı üzerine yapılan incelemeler de yoğunlaşmıştır (Oskay, 2004, s. 7).

İmgelem ise sözlük anlamı olarak; 1. Geçmiş yaşantılara özgü öğelerle şimdiki yaşantılar arasında bağ kurma gücü. 2. Nesnelerin biçimlerini zihinde tasarımlayabilme yetisi 3. Bir nesneyi, o nesne (karşımızda) olmaksızın tasarımlama yetisidir. İmgelem: a. Yaratıcı olabilir, tasarımı kendisi yaratır, b. Yansıtıcı olabilir, zihinde önceden bulunan tasarımları anımsar ("TDK", t.y.).

İmgelem, imgeler arasında yeni ilişkiler kurma, yeni kavram ve düşünceler oluşturma yetisi olarak da tanımlanabilir. Burada bilinç söz konusudur. Aslında imgelem her insanın yaptığı, yapabildiği, insana özgü bir yetenektir (Işıldak, 2008, s. 66). Hall'e (2001) göre; imgeleme, gerçek yaşantıların taklit edildiği bir yaşantıdır. İmgelediğimiz şeyi gördügüumüzü fark edebiliriz, imgelerken hareketleri hissedebiliriz ya da gerçek yaşantılar olmadan da seslerin, tatların ve kokuların imgelerini yaşayabiliriz (aktaran Kızıldağ ve Tiryaki, 2012, s. 14).

İmgelem, duyularımızla edindiğimiz ya da zihnimizde oluşturduğumuz imgeler arasında bağıntılar kurmaya, imgeleri yeniden düzenlemeye ve değişiklikler yapmaya yarar ve düşünme sürecinin büyük bir bölümü imgelem alanında geçer. Birey, imgelem sayesinde daha önceki deneyimlerinden, yaşantılarından edindiği imgeleri birleştirerek yeni imgeler elde edebilir ve bu imgeleri ile yaratıcı tasarımlar oluşturabilir. İmgelem, bireyin duyumsal, duygusal ve düşünsel süreçlerini harekete geçirir ve yaratıcı düşünme anında bu yetilerin birbirleriyle yoğun bir şekilde etkileşim içine girerek, yeni tasarımlar oluşturmasını sağlar (Oskay, 2004, s. 36).

Eğitimde etkili bir öğretim yöntemi olarak imgelerin kullanımı, eskiden olduğu gibi günümüzde de geçerli ve önemlidir. Oyunculuk, dans, resim, müzik, spor vb. birçok alanda eğitimde sözel imgelerden yararlanılmaktadır. Sanat ve müzik eğitiminde sözel imgeler, estetik anlayış ve sanatsal ya da müzikal sonuçların kazanılması için kavramların ifade edilmesinde bir araç olarak kullanılır. Müzisyenler için belli bir müzikal sesin üretilmesi ve performansı ve sanatsal ifade nihai amaçlardır. Bu amaçların başarılması için sanatçılar ve eğitmenler sözlü imgeye gereksinim duyarlar. Çünkü başarılı performans için, doğru ses ya da yorumun kavramsallaştırılmasında sözlü imge bir koşuldur (Wei, 2006, s. 3).

Vokal pedagoji, (ses pedagojisi) öğrencilerin teknik becerilerini ve müzikal ifadelerini, hem sistematik ve metodik, aynı zamanda yaratıcı ve esnek bir şekilde kapsamlı bilgi ve kompleks beceriler sunulması yoluyla geliştirmelerine yardım etme ile ilgilidir. Bu nedenle iyi bir ses eğitmeni, yalnızca yetkin vokal tekniklerin niteliklerine sahip 
olmaya değil, aynı zamanda gelişmiş, çok yönlü ve ileri öğretim yöntemleri edinmeye gereksinim duyar (Wei, 2006, s. 27)

Yirmi birinci yüzyılın ses eğitimi öğrencisini eğitirken, bugünün ses eğitmeninin öğretimini geliştirmek ve zenginleştirmek için çeşitli teknikler kullanması gerekir. Ses eğitiminde her öğrenci kendine özgü bir birey olduğundan, öğretmeninden farklı bir eğitim yöntemi talep eder. Bu nedenle, öğretmenler pedagojik ilkeleri öğrencilerine açıklamak için çeşitli yöntemler geliştirmişlerdir. Yöntem olarak, sadece bilimsel yaklaşımı kullanan öğretmenler olduğu gibi, sadece imge ve analojileri kullanan öğretmenler ve her ikisinin kombinasyonunu kullanan öğretmenler vardır. Bilimsel eğitime dayalı yaklaşımda, konular çoğunlukla kuramsal olarak tanımlanıp düz anlatım yoluyla aktarılırken, imgelerin kullanıldığı eğitim yaklaşımında, bireyin hayal gücü temel alınarak yaşamdan örneklerle kazandırılmak istenen bilgi ve davranış arasında bağlantılar kurulup zihinde canlandırılması sağlanır. Örneğin, ses eğitiminde doğru solunum tekniğini kazandırmak için "nefes al ve havayı akciğerlerinin altına doğru yerleştir" komutu yerine, "çiçek koklar gibi ya da güzel bir kokuyu içine çeker gibi nefes al" imgesi daha kolay ve anlaşılır olabilir. Yine, "birden çok korkmuş ya da şaşırmış gibi nefes al” imgesi, ağızdan alınan hızlı ve doğru solunum tekniğini yerleştirmede daha etkili olabilir. Bu çalışmanın konusu olan ses eğitiminin temel konularına ilişkin örnek imgeler Tablo 2'de daha ayrıntılı sunulmuştur. Elbette eğitimin farklı alanlarında, farklı ve çok çeşitli imgeler kullanılabilir. Eğitimde imgelerin kullanıldığı öğretim, yaşamdan örneklerin uygulanmasıyla renkli ve eğlenceli olabilirken, imgelerden yoksun öğretim birçok öğrenci, özellikle yeni başlayanlar için sıkıcı ve anlaşılması zor olabilir. Çünkü konuların bilimsel tanımlarla ve düz bir anlatımla aktarılmasıyla, ders süresi boyunca öğrencilerin ilgi, istek, dikkat ve motivasyonlarını sağlamak zor olabilmektedir. Bilimsel eğitim yaklaşımı elbette gereklidir, ancak hem imgelerin hem de bilimsel ilkelerin kullanımını dengeleyen bir öğretim yöntemi daha doğru ve yararlı olabilir.

Vennard'ın (1967) vurguladığı da, bilimsel gerçek ve imgeleri birleştirmenin gerekliliğidir. "Bilimsel dil bir sanatın öğretilmesinde yetersizdir ve biz eksikliği şiirsel imgelerle dolduruyoruz. Hayal olanı gerçekle karıştırmadığımız sürece, bu bizim anlayışımızın ötesinde olan ancak yine de pratik açıdan yararlı olabilecek gerçekleri bulma aracı olabilir.” (s. 147). Vennard, ses eğitiminde başarıyı elde edebilmek için, yirmi birinci yüzyıl öğretmeninin geçmişten öğrenmesi ve bu kanıtlanmış pedagojik kavramları, şimdiki dil, fikir ve imge kullanımlarıyla birleştirmesi gerektiğine inanmaktadır.

McKinney (1994), Vennard'ın imge kullanımı konusundaki dengeli yaklaşımına şu şekilde katılmaktadır:

Bir... problem şarkı söyleme eyleminde kullanılan mekanik ve psikolojik kontrollerden kaynaklanabilir. Mekanistik yaklaşımın aşırı savunucuları, şarkı söylemenin, büyük oranda doğru parçaları doğru zamanda doğru yerde elde etme meselesi olduğuna ve iyi çalışmayan kısımlara doğrudan dikkat çekerek ses hatalarının düzeltilmesinin sağlandığına inanmaktadır. Diğer uçta, dikkatin hiçbir zaman ses mekanizmasının herhangi bir kısmına yönlendirilmemesi gerektiğine inananlar -ki şarkı söylemenin istenen tonun doğru zihinsel imgesini üretme meselesi olduğu ve ses hatalarının düzeltilmesinin doğru düşüncelerle düşünmeyi öğrenerek ve müziğin yorumlanmasıyla duyguları serbest bırakarak elde edilmesi gerektiğidir. Çoğu zaman olduğu gibi gerçek, bu iki uç arasında yatmaktadır ve her iki yaklaşımın bir birleşimidir (s. 31).

Freed (2000), Vennard ve McKinney'in gerçeğe dayalı imgelem yaklaşımına katılarak şöyle belirtmektedir: "Öğretmen, imgelem ile fizyolojik gerçeğin arasındaki farkı kesinlikle bilmelidir. Daha sıklıkla, imge, fizyolojik bir ilkeyi güçlendirmeye yardımcı olmalı ve fark açıklanmalıdır” (aktaran Clements, 2008, s. 3).

Hemsley (1998) ise, konuya şöyle yaklaşmaktadır:

Her şeyi mekanik bir modele indirgemeye çalışan bilim, insanın şarkı söyleme eylemine uygun değil. Aslında eski, bilim-öncesi günlerin bilgeliği, bazen kişisel şarkı söyleme deneyimi olmayan ya da gerçek bilimsel prensiplerin yüzeysel anlayışından daha fazlasına sahip olmayan öğretmenlerin öne sürdüğü açıklamalardan bazılarına göre daha gerçek, daha bilimseldir. Çünkü insan duygularının ve algılarının bilgisi ile ilgilidir. Anatomi ve fizyolojinin anlaşılması, eğer doğruysa, şarkıcıların problemleriyle başa çıkmada öğretmenlere yardımcı olabilir. Ancak anatomi ile çok fazla ilgili olma ve şarkıcı adına, şarkı söylemenin tamamen mekanik, anatomik yönleriyle ilgilenme, aslında onların şarkı söyleme yeteneklerini engelleyebilir. Gerçekten de sıklıkla anatomi ile aşırı ilgilenme, sesle ilgili birçok sorunun nedeni olabilir (s. 9).

Ses eğitiminde imgelemin kullanılması yeni bir fikir değildir. Fields (1972), ses eğitimi ve imgelemin ilişkisini şu sözlerle ifade etmektedir:

Zihinsel imgelem, vokal anlatımın planını ve amacını sağlar. Seslerin oluşumu ve yeterli izdüşümü, bu temel kavramların doğrudan sonuçlarıdır ve bu nedenle vokal ifadenin, şarkıcının görselleştirme ve zihinsel imgelem güçleri tarafindan yönetildiği söylenir. Temelde, söyleyen ses değil, "ZİHİN" dir. Ses düşünceleri takip ettiğinden, ne düşündüğünü sözle (konuşarak) ya da şarkı söyleyerek ifade edebilirsin. ...Dolayısıyla 
düşünce içinde şarkı söylemeyi öğrenmeliyiz. Çünkü ses onu üreten düşüncenin içinde yerleşmiştir (aktaran Clements, 2008, s. 2).

Bir eğitmen imgeleri kullanarak, her öğrenciye öğrencinin anlayacağı bir dilde ve şekilde yardımcı olmak için kendi öğretimini ayarlayabilir. Winsel (1966), "Tekniği öğrenciye bireysel olarak onun mizacına göre, anlayacağ terimleri kullanarak açıklamalıyız. Ses üretiminin temelleri değişmez, ancak bu gerçeklerin uygulanması, her öğrencinin kendi tarzında anlaşılmalıdır, dolayısıyla bu uygulamanın sınırsız çeşitliliği olmalıdır" şeklinde ifade etmektedir (aktaran Clements, 2008, s. 3).

Ömür'e (2001) göre, insan sesinin güzel ve güçlü çıkması, akciğer, gırtlak ve rezonans boşluklarının her birinin ayrı ayrı iyi çalışması ile ilgili değil, organlar arası uyumla ilgilidir. Müzik enstrümanlarında nöromusküler (sinirkas) koordinasyon, görme ve dokunma duyularından yararlanarak sağlanır. Ancak şarkı söylemeyi öğrenirken böyle kolaylıklar yoktur. Ayrıca öğrenci, daha önce alıştığı konuşma ile ilgili nöromusküler uyarılardan vazgeçip tamamen farklı bir koordinasyon sağlamak zorundadır ve bu da oldukça zor bir iştir. Bu güçlüklere müzikal kaygılar, ifade ve şarkı sözlerinin anlaşılır olması çabası da eklenince durum daha da zorlaşır. Bu noktada, nöromusküler (sinir-kas) koordinasyonun gerçekleşmesi için ses eğitmenleri, öğrencilerinden fizyolojik gerçeklere uymayan bazı imajlarla çalışmalarını isterler. Bazı ses organlarına istemli olarak hükmetmek mümkün olmadığından, "boğazını aç”, "gırtlağını aşağıya çek”, "damağını kaldır” gibi öneriler, yeni başlayan bir ses eğitimi öğrencisi için anlaşılması zor kavramlardır. Ancak bir süre sonra istenilenleri yapabilecek duruma gelen öğrencide, normal olarak istemsiz olan bu hareketler kontrol edilir duruma gelir. Üstelik, kasların çok ince ve hassas motor ayarlarının yapılabilmesi de mümkün olur. Bunun nasıl olduğu konusunda yapılan psikolojik araştırmalar, bir hareketi yapmayı düşünmenin, o hareketi yapmayı kolaylaştırdığını göstermiştir. Ayrıca bu hareket hafızaya alınıp birtakım şemalar ya da imajlar olarak birikmektedir (s. 48).

Bir şarkıcının kendi enstrümanı yani sesi üzerindeki birincil kontrolü kasla ilgili değil, zihinseldir. Bu, şarkıcının kulağı ve sesi arasındaki doğal koordinasyonun yanı sıra, müzikal sesleri ve konuşma seslerini tam olarak hayal edebilmesi için gerekli doğal bir yeteneğe dayanır. Bu yetenek, bu ek koordinasyon ve şarkıcının hayal ettiği sesleri yeniden üretmesini sağlayan yapının vokal aygıtı, herhangi bir pratik mesleki amaç için çalışılarak elde edilemeyen özelliklerdir. Bununla birlikte, bu tür özellikler varsa geliştirilebilir. Verimli ve etkili bir vokal tekniğin edinilmesine yönelik herhangi doğru ve akılcı bir yaklaşım bunu dikkate almalıdır. Ses üretiminde rol oynayan belirli kaslar üzerinde doğrudan bilinçli kontrolün kazanılması, vokal teknik çalışmasında sadece tamamlayıcı, ikincil bir amaç olarak kabul edilebilir. Bu yaklaşım genellikle, vokal tekniğin temel amacı olarak kabul edilir ve bir ses imgesi oluşturulması yoluyla, birinin ses aygıtının zihinsel kontrolü için değiştirilir- onun yerine kullanılır. Bir jimnastikte mekanik bir tarzda böyle bir kas kontrolü elde etme girişimi, genellikle ses eğitimi alan öğrencinin sesi ile kulağı arasındaki doğal koordinasyonu bozar. Diğer bir deyişle, öğrencinin şarkı söylemedeki verimi düşer (Kagen, 1960, s. 46). Ses eğitimi alan bir öğrenci, yeteneğini en iyi şekilde kullanıncaya ve üretmek istediği sesin ya da ses dizisinin belirli, kesin bir imgesine ulaşana kadar, kendine şarkı söylemek için izin vermemelidir. Böyle bir imge oluşturmadan önce şarkı söylemek, sadece öğrencinin kafasını karıştıracaktır. Belki de, şarkı söyleme becerisi ortalama olan bir öğrenciye, kendi bilinçsiz ve tesadüfî uygulama tarzıyla, başka hiçbir şeyin veremeyeceği kadar fazla zarar verilir. Bir ses eğitimi öğrencisi, sesi ile bir şeyler yapmanın bir yolunu bulmayı ümit edebilmek için, öncelikle ne yapmak istediği konusunda bilinçlendirilmelidir. Çünkü öğrenci, kendi zihninde fazla net olmayan bir şeyi tam olarak nasıl uygulayacağı konusunda başarılı olamaz (Kagen, 1960, s. 49-56).

Ses eğitiminde önemli bir rolü olan imgelemi öneren birçok ses pedagogu olmakla birlikte Wei (2006) ve Hemsley (1998): "Şarkıcılar, esnek ve canlı bir şekilde uyanık olmaları ve hayal güçlerinin çalışmalarına tam olarak yanıt vermesi için gerekli olan zihinsel ve fiziksel dengeyi kaybetmeden, sahip oldukları fiziksel ve zihinsel enerjiyi harekete geçirmeyi öğrenmelidirler. Bu, teknik denilen şeyin temel şartlarından biridir” diyerek konuyu güzel bir şekilde özetlemektedir.

Buraya kadar anlatılanların 1şı̆̆ında genel bir değerlendirme yapmak gerekirse; bilim, teknoloji ve sanat alanlarında nitelikli bireylerin yetiştirilmesi, nitelikli bir toplumun oluşmasında ve gelişmesinde temel hedeflerden biridir. Nitelikli bireylerin yetiştirilmesi ile ilgili olan öğretmenlik mesleği genel olarak konuşma ile doğrudan ilişkilidir ve sesin uzun süre kullanılmasını gerektirmektedir. Müzik öğretmenleri ise hem konuşma hem de şarkı söyleme ve öğretme yoluyla seslerini daha çok kullanmak durumundadırlar. Bu nedenle, müzik öğretmeni adaylarının seslerini en iyi şekilde kullanabilmeleri için, nitelikli bir eğitim almaları daha çok önem kazanmaktadır. Müzik öğretmeni yetiştirme kapsamında yer alan "Ses Eğitimi” dersinde, öğretmen adaylarının en temel ve doğal iletişim ve müzikal ifade aracı olan seslerinin doğal hali korunarak, konuşma ve şarkı söyleme becerilerinin geliştirilmesi amaçlanmaktadır. Bu bağlamda, bu amaca uygun olarak kullanılacak eğitim yöntemlerinin doğru seçimi ve uygulanması önem kazanmaktadır. Eski ve günümüz şan pedagogları tarafından, ses eğitiminin temel süreçlerine yönelik bilgi ve becerileri kazandırmak ve sonuçta tüm süreçlerin koordinasyonu ile gerçekleşen doğru, rahat ve güzel şarkı söyleme becerisini geliştirmek amacıyla ses eğitimi derslerinde kullanılan sözel imgelere dayalı eğitim bu amaca hizmet edebilir. 
Bu gerekçeler doğrultusunda bu araştırmanın amacı, sözel imgelerin, müzik öğretmeni adaylarının şarkı söyleme becerileri üzerindeki etkisini araştırmaktır. Buna göre, araştırmanın problem cümlesi şöyle ifade edilebilir: Müzik öğretmenliği lisans programında yer alan "Ses Eğitimi”" dersinde kullanılan sözel imgelere dayalı eğitimin, müzik öğretmeni adaylarının şarkı söyleme becerileri üzerindeki etkisi nedir?

\section{Yöntem}

$\mathrm{Bu}$ araştırma, deneysel bir araştırmadır. Öntest-sontest kontrol gruplu deney deseninin kullanıldığı araştırmada, rastlantısal olarak seçilen 5 öğrenci deney grubunu, 5 öğrenci ise kontrol grubunu oluşturmuştur. Öğrencilerin 2018-2019 öğretim yılı başındaki şarkı söyleme performansları, biri araştırmacı olmak üzere iki ses eğitmeni tarafindan değerlendirilmiştir. On iki hafta süren deney sürecinde, araştırmacı tarafından kontrol grubunu oluşturan deneklere haftada bir saat bilimsel yönteme dayalı (konuların kuramsal temele dayalı, düz anlatımla verildiği)ses eğitimi, deney grubunu oluşturan deneklere haftada bir saat bilimsel yönteme dayalı bireysel ses eğitimi yanında sözel imgelere dayalı ses eğitimi verilmiştir. Dönem sonunda, aynı öğretim elemanları tarafından her iki grubun performansları yeniden değerlendirilerek, deney öncesi ve deney sonrası değerlendirme sonuçları arasında, deney grubunun lehine anlamlı düzeyde gelişme olup olmadığı istatistiksel açıdan test edilmiştir.

\section{1. Çalışma Grubu}

Araştırma, 2018-2019 öğretim yılı güz döneminde, Türkiye’nin İzmir ilindeki Dokuz Eylül Üniversitesi Buca Eğitim Fakültesi Müzik Eğitimi Anabilim Dalı'nda 1. sınıfta öğrenim gören 10 öğrenci ile yürütülmüştür. Araştırmada deney ve kontrol gruplarının homojen olmasına özen gösterilmiştir. Deney ve kontrol grubunu oluşturan öğrenciler, yaş, cinsiyet ve derse hazır bulunma düzeyi açısından denktirler. Öğrencilerin hepsi kız olup, 18-20 yaş aralığındadırlar. Güzel Sanatlar Lisesi Müzik Eğitimi Bölümü’nden mezun öğrenciler olmaları nedeniyle daha önce Ses Eğitimi dersi almışlardır. Ancak, öğrenciler dersleri grup şeklinde aldıklarını, bu nedenle yararlı ve verimli olmadığını belirtmişlerdir. Araştırma sürecinde de, öğrencilerin gerek kuramsal gerekse uygulama düzeyinde oldukça yetersiz oldukları gözlenmiştir.

\subsection{Deney Deseni}

Bu araştırmada öntest-sontest kontrol gruplu deney deseni kullanılmıştır. Deney deseni Tablo 1'de, deney grubuna uygulanan sözel imgelerle ses eğitimi çalışmalarına örnek cümleler Tablo 2'de yer almaktadır.

Tablo 1

Deney deseni

\begin{tabular}{cccc}
\hline Gruplar & Ölçüm (Ön-test) & Denel İşlemler & Ölçüm (Son-test) \\
\hline Kontrol Grubu & Şarkı Söyleme & *Bilimsel Yönteme Dayalı Bireysel Ses Eğitimi & Şarkı Söyleme Becerisi \\
$\mathrm{N}=5$ & Becerisi & 12 hafta / haftada 1 saat & Gözlem Formu \\
& Gözlem Formu & & \\
Şarkı Söyleme & *Bilimsel Yönteme ve Sözel İmgelere Dayalı Bireysel & Şarkı Söyleme Becerisi \\
Deney Grubu & Becerisi & Ses Eğitimi & Gözlem Formu \\
$\mathrm{N}=5$ & Gözlem Formu & 12 hafta / haftada 1 saat & \\
& & & \\
\hline
\end{tabular}

Tablo 2

Sözel imgelere dayalı ses eğitimi çalışmalarına örnek cümleler

\begin{tabular}{|c|c|c|}
\hline Denekler & $\begin{array}{c}\text { Ses Eğitimi } \\
\text { Temel Konular }\end{array}$ & Örnek Cümleler \\
\hline \multirow[b]{2}{*}{$\begin{array}{l}\text { Deney Grubu } \\
\qquad \mathbf{N}=\mathbf{5}\end{array}$} & $\begin{array}{l}\text { Postür (Doğru ve } \\
\text { dengeli vücut } \\
\text { duruşu) öğretimi } \\
\text { için kullanılan } \\
\text { sözel imgelere } \\
\text { örnekler }\end{array}$ & $\begin{array}{l}\text { *Kendinizi asil biri gibi düşünün ve o şekilde durun. } \\
\text { *Vücudunuzu uzun ve güçlü bir ağaç olarak konumlandırılmış şekilde düşünün. } \\
\text { *Ayaklarınızı sanki güzel çiçek saksıları gibi yere sağlam bir şekilde yerleştirin. } \\
\text { *Kafanızın tepesinden ayaklarınıza kadar uzanan lazer ışını hayal edin. } \\
\text { *Doğru yükseklik içcin boyunuz ölçülüyormuş gibi düz durun. } \\
\text { *Sanki bir kukla gibi kafanızın tepesinde bir iple bağlı olduğunuzu hayal edin. } \\
\text { *Göğsünüzün önünde sıkıca gerilmiş elastik bant tuttuğunuzu hayal edin. } \\
\text { *İpte adım atan bir ip cambazı gibi durun. } \\
\text { *Okçunun okunu serbest bırakmasından hemen önce olduğu gibi durun. } \\
\text { *Bir orkestra şefi gibi (havada ve dengeli batonuyla) durun. } \\
\text { *Yüksek bir dalıșa hazır olimpik bir yüzücü gibi durun. }\end{array}$ \\
\hline & $\begin{array}{c}\text { Solunum ve } \\
\text { destek (Sesin } \\
\text { enerji kaynağı) } \\
\text { öğretimi için } \\
\text { kullanılan sözel } \\
\text { imgelere örnekler }\end{array}$ & $\begin{array}{c}\text { *Bir gülü koklar gibi nefes alın. } \\
\text { *Sanki esner gibi nefes alın. } \\
\text { *Sanki iç çeker gibi nefes alın. } \\
\text { *Tüm şarkı cümlesini içinize çekin. } \\
\text { *Akciğerler ve vücut körük gibi çalışsın. } \\
\text { *Bir hava yastığı (nefes) üzerinde şarkı söyleyin. } \\
\text { *Bir pipetten su içer gibi nefes alın. } \\
\text { *Vücudun içine, aşağı ve dışarı doğru nefes alın, } \\
\text { *Yukarı doğru fışkıran su (nefes) üzerinde top (ses) dengeleme durumunu hayal edin. } \\
\text { *Denizde bol miktarda hava ile derine dalan bir dalgıç gibi nefes alın. } \\
\text { *Sanki bir bardak su içiyor gibi nefes alın. } \\
\text { *Bina (ses) ne kadar yüksekse, temel (nefes) o kadar derin-sağlam olmalı. }\end{array}$ \\
\hline
\end{tabular}


Tablo 2'nin devamı

\begin{tabular}{|c|c|c|}
\hline Denekler & $\begin{array}{c}\text { Ses Eğitimi } \\
\text { Temel Konular }\end{array}$ & Örnek Cümleler \\
\hline \multirow{3}{*}{$\begin{array}{l}\text { Deney Grubu } \\
\mathbf{N}=\mathbf{5}\end{array}$} & $\begin{array}{l}\text { Fonasyon (Ses } \\
\text { tellerinin titreşimi } \\
\text { ile sesin oluştuğu } \\
\text { süreç) öğretimi } \\
\text { için kullanılan } \\
\text { sözel imgelere } \\
\text { örnekler }\end{array}$ & $\begin{array}{l}\text { *Sesinizi yüzün önünde, maskede düşünün ve burnun her iki yanında tınlamayı hissedin. } \\
\text { *Yumuşak damağı kaldırın, çeneyi ve dili rahatlatın ve ses akışını sağlayın. } \\
\text { *Bir kelebek gibi dalgalanan bir ton (değişen-sabit olmayan) hayal edin. } \\
\text { *Yumurta şeklinde bir ağız pozisyonu düşünün. } \\
\text { *Bir pırlanta-elmas gibi parlayan bir ton hayal edin. } \\
\text { *Yumuşak ya da ipeksi bir ton düşünün. } \\
\text { *Sesi döndürün. } \\
\text { *Doğal olarak şarkı söyleyin, zorlanmadan. } \\
\text { *Tonu yuvarlayın. } \\
\text { *Sesi (ıslık çalar gibi, bir düdüğe, boruya üfler gibi) odaklayın. } \\
\text { *Sesi aşağıdan değil, yukarıdan görün. } \\
\text { *Kadife gibi, yumuşak dokulu, pürüzsüz bir ton hayal edin. } \\
\text { *Kuş gibi şarkı söyleyin. } \\
\text { *Tonda bir bahar-aydınlık hissedin. } \\
\text { *Sesi kusturun. } \\
\text { *Bir noktada ses çıkarın. } \\
\text { *Tonun kendi kendine başlamasına, kendi kendine uzamasına ve kendi kendine durmasına izin } \\
\text { verin. } \\
\text { *Güzel bir ton üretme ve sürdürme arzusuna sahip olun. } \\
\text { *Sesinizi bir çizgi üzerinde sürdürün. } \\
\text { *Nefesle değil, nefesin üzerinde söyleyin ya da “Ton nefesin üzerinde yüzüyor gibi söyleyin.” }\end{array}$ \\
\hline & $\begin{array}{c}\text { Rezonans } \\
\text { öğretimi için } \\
\text { kullanılan sözel } \\
\text { imgelere örnekler }\end{array}$ & $\begin{array}{l}\text { *Armut biçimli bir tonla şarkı söyleyin. (Geniş bölümü yumuşak damağa doğru boğazın } \\
\text { arkasında bir armut düşünün, üst kısmı kafatasının tepesine doğru baksın.) } \\
\text { *Tüm vokal çabalar, girtlak yerine kafadan geliyormuş gibi hissedin. } \\
\text { *Başı, kendisinin iki katı büyüklüğ̈nde ve sesle dolu hayal edin. } \\
\text { *Boğazın arkasında kubbe veya kemer hayal edin. } \\
\text { *Ağızda ters megafon hayal edin. } \\
\text { *Yüzün önünde, maskede titreşim hissedin } \\
\text { *Elmacık kemiklerinin üzerindeki tonlara odaklanın. } \\
\text { *Burun köküne, gözlerin arasına doğru şarkı söyleyin. } \\
\text { *Sesi, enerjik bir hareketle ileriye uçan bir uçak olarak düşünün. } \\
\text { *Sesin titreşimini dil üzerinde hissedin. } \\
\text { *Tüm ses alanı- bir ses bölgesi yani "Yüz Bölgesi” olsun. } \\
\text { *Ağzınızda sıcak patates varmış gibi düşünün. } \\
\text { *Yumuşak, geniş bir boğazla şarkı söyleyin. } \\
\text { *Zeminde kalmak yerine tavana yükselin (damağ1 kaldırın). }\end{array}$ \\
\hline & $\begin{array}{l}\text { Artikülasyon } \\
\text { (Sesin konuşma } \\
\text { seslerine ve } \\
\text { sözcüklere } \\
\text { dönüşstüğü süreç) } \\
\text { öğretimi için } \\
\text { kullanılan sözel } \\
\text { imgelere örnekler }\end{array}$ & $\begin{array}{c}\begin{array}{r}\text { *Dil ucunun üzerinde yer alan ve süren ünlü harfler düşünün. } \\
\text { *Ünlü harfleri ses için bir iskelet olarak düşünün. } \\
\text { *Ünlü harfleri tutmaya devam edin. } \\
\text { *Ünlü harfleri yuvarlayın. } \\
\text { *Dilin ucunu serbest bırakın }\end{array} \\
\text { *A ğgzınızda yumurta varmış gibi çenenizi iyice açın. } \\
\text { *Ünlülere ağız içinde yer açın. } \\
\text { *Dudaklar, dişler, dilin ucu serbest olsun. } \\
\text { *Uzun boylu sesli harflerle şarkı söyleyin. } \\
\text { *U ünlüsü için ağzınızı esner gibi açın. } \\
\text { *Ün, Ü ve O, Ö ünlülerini birini öpecekmiş gibi dudakları hafif öne uzatarak söyleyin ya da } \\
\text { küçük sevimli bir balık ağzı gibi düşünerek konumlandırın. } \\
\text { *Dudaklarınızı okumak zorunda olan birine ya da dilinizi çok iyi bilmeyen birine şarkı } \\
\text { söylediğinizi hayal edin. } \\
\text { *Metropolitan Operası'nda şarkı söylüyorsunuz, küçük bir stüdyoda değil. } \\
\text { * Konser salonunda en arkada olan insanların bile ne söylediğinizi anlayabileceğini düşünün. } \\
\text { *Konuştuğunuz gibi şarkı söyleyin. }\end{array}$ \\
\hline
\end{tabular}

Deney ve kontrol gruplarına haftada bir saat uygulanan "Bilimsel Yönteme Dayalı Ses Eğitimi” dersinde ise şu çalışmalara yer verilmiştir:

1. Hafta: Öğrencilerin "Ses Eğitimi” dersinin amacı ve önemi konusunda bilgilendirilmesi. Ses anatomisi ve sesin oluşumu ile sesin oluşumunda görev alan organların yapısı ve çalışması konularında gerekli bilgilerin verilmesi.

2. Hafta: Bedensel ve zihinsel olarak şarkı söylemeye hazırlanma çalışmaları ve bunun önemi konusunda gerekli bilincin kazandırılması. Postür (doğru ve dengeli vücut duruşu) çalışmaları ve ses eğitiminde postürün önemi konusunda gerekli bilincin kazandırılması. Şarkı söylemede solunum çalışmaları ile doğru solunum alışkanlığının kazandırılması.

3. Hafta: Derse hazırlık çalışmaları (bedensel ve zihinsel olarak rahatlama, doğru ve dengeli duruş ve solunum çalışmaları). Tek ses üzerinde, daha sonra ikili ve üçlü aralıklarda kapalı ağızla ve uygun hecelerle yapılan egzersizlerle ses-soluk bağlantısının kurulması ve solunum kontrolünün sağlanması çalışmaları. 
4. Hafta: Derse hazırlık çalışmaları. Tek ses üzerinde, daha sonra ikili, üçlü, dörtlü ve beşli aralıklarda, sıralı ve aralıklı ses egzersizleriyle, sesi doğru pozisyonda ve doğru entonasyonla üretme ve rezonans bölgelerinde sesi güçlendirme ve tını kazandırma çalışmaları. Başlangıç metodundan ve şan literatüründen seçilen uygun şarkılar üzerinde bu çalışmaların pekiştirilmesi.

5. Hafta: Derse hazırlık çalışmaları ve ses egzersizleri. Doğru telaffuz ve artikülasyon becerisi kazandırmaya yönelik, vokal (ünlü harf) ve konsonların (ünsüz harf) incelenmesi ve doğru pozisyonda söylenmesi çalışmaları. Başlangıç metodundan ve şan literatüründen seçilen uygun şarkılar üzerinde bu çalışmaların pekiştirilmesi.

6. Hafta: Derse hazırlık çalışmaları ve ses egzersizleri. Başlangıç metodundan ve şan literatüründen seçilen uygun şarkılar üzerinde öğrenilen becerilerin pekiştirilmesi. Yanı sıra piyano eşlikli halk türkülerinden yararlanarak, Türk dilinin ünlü ve ünsüzlerini doğru artikülasyonla oluşturma çalışmaları.

7. Hafta: Derse hazırlık çalışmaları. Tek ses üzerinde, daha sonra ikili, üçlü, dörtlü, beşli ve oktav aralıklarında sıralı sesler ve arpej çalışmaları ile legato (bağlı) ve staccato (kesik kesik) söyleme çalıșmaları. Şarkıların güzel yorumlanmasına yönelik nüans çalıșmaları. Başlangıç metodundan ve şan literatüründen seçilen uygun şarkılar üzerinde bu çalışmaların pekiştirilmesi.

8. Hafta: Derse hazırlık çalışmaları. Doğru solunuma dayalı doğru fonasyon, doğru rezonans ve doğru artikülasyonun eşgüdüm içerisinde oluşturulabilmesine yönelik bireye özgü ses alıştırmaları. Ses alanlarının (rejister) kavratılması amacıyla, doğru ve uygun rejister geçişlerine yönelik alıştırmalar. Seçilen etüt ve eserler üzerinde bu çalışmaların pekiştirilmesi.

9. Hafta: Derse hazırlık çalışmaları ve ses egzersizleri. Şarkıların dönem özelliklerine ve türlerine uygun stilde söylenmesi amacıyla gerekli bilgilerin verilmesi ve örnek eserlerin dinletilmesi. Çalışılan eserler üzerinde doğru stilde söyleme ve yorumlama çalıșmaları.

10. Hafta: Derse hazırlık çalışmaları ve ses egzersizleri. Çalışılan eserler üzerinde doğru stilde söyleme ve yorumlama çalışmalarının sürdürülmesi.

11. Hafta: Derse hazırlık çalışmaları ve ses egzersizleri. Doğru sesin oluşumunda gereken eşgüdümün sağlanabilmesine ve doğru entonasyonla müzikal duyarlılığı geliştirmeye yönelik ses alıştırmaları, ses etütleri ve öğrenci düzeyine uygun eserlerin yorumlanması ve piyano eşlikli çalışılması.

12. Hafta: Derse hazırlık çalışmaları. Öğrenilen bilgi ve becerilerin tekrarına ve pekiştirilmesine yönelik her öğrenciye uygun ses çalışmaları ile seçilen şarkıların piyano eşlikli çalışılması ve yorumlanması çalıșmaları.

\subsection{Verilerin toplanması}

Araştırmada verilerin elde edilmesi amacıyla, Ses Eğitimi (SE) dersi hedef ve hedef davranışlarına yönelik araştırmacı tarafından daha önce geliştirilen, "Şarkı Söyleme Becerisine Yönelik Gözlem Formu” kullanılmıştır (Ek 1). Gözlem formu, 20 ses eğitimi uzmanının görüşüne sunulmuş, ses eğitmenlerinin görüş ve önerileri doğrultusunda gerekli değişiklikler ve düzeltmeler yapılarak forma son şekli verilmiştir. Formda, hedef ve hedef davranışlara yönelik her bir maddenin değerlendirilmesi için 1 ile 5 puan arasında seçenekler bulunmaktadır. Gözlem formu, son şekliyle Dokuz Eylül Üniversitesi Buca Eğitim Fakültesi Güzel Sanatlar Eğitimi Bölümü Müzik Eğitimi Anabilim Dalı'nda Ses Eğitimi derslerini yürüten iki ses eğitmeni tarafından, aynı kurumda öğrenim gören ve Ses Eğitimi dersi alan 25 öğrenciye uygulanmıştır. İki ses eğitmeni, birbirlerinden bağımsız olarak öğrencilerin şarkı söyleme performanslarını gözlem formuyla değerlendirmişlerdir. Araştırmada elde edilen veriler, analiz edilerek iki ses eğitmeninin değerlendirmesi arasındaki pearson korelasyon katsayısı ve Cronbach Alpha güvenirlik katsayısına bakılmıştır. Elde edilen sonuç $(r=0.85, p=.000, p<.01)$, ses eğitmenleri arasında pozitif ve anlamlı bir ilişki olduğunu göstermiştir. İki gözlemci arasında pozitif ve anlamlı bir ilişki olması ve güvenirlik katsayısının yüksek olması, geliştirilen gözlem formunun, Ses Eğitimi dersinin hedefleri doğrultusunda öğrencide gelişmesi gereken hedef davranışları ölçebilecek geçerlik ve güvenirlikte olduğunu göstermektedir. Analiz sonuçları, Tablo 3 ve Tablo 4'de verilmiştir.

Tablo 3

Puanlayıcıların öndeneme puanlamaları arasındaki korelasyon tablosu

\begin{tabular}{lccc}
\hline & $\mathbf{N}=\mathbf{2 5}$ & 1.Puanlayıc & 2.Puanlayıcı \\
\hline 1.Puanlayıcı & Korelasyon Katsayısı & 1 & .850 \\
& P & .850 & .000 \\
2.Puanlayıcı & Korelasyon Katsayısı & .000 & 1 \\
\hline
\end{tabular}

Tablo 4

Şarkı söyleme becerisine yönelik gözlem formu cronbach alpha güvenirlik tablosu

\begin{tabular}{rrr}
\hline \multirow{2}{*}{ Ön deneme } & $\mathrm{N}$ & Cronbach Alpha Katsayisı \\
\cline { 2 - 3 } & 16 & 0.892
\end{tabular}




\subsection{Verilerin Analizi}

$\mathrm{Bu}$ araştırmada, Ses Eğitimi dersinin hedef ve hedef davranışlarının değerlendirilmesine yönelik hazırlanan gözlem formu, biri araştırmacının kendisi olmak üzere, iki ses eğitmeni tarafından deney ve kontrol gruplarından oluşan toplam 10 öğrenciye uygulanmıştır. Araştırmanın verileri, SPSS 23.0 programı ile analiz edilmiştir. Araştırmada, iki ses eğitmeninin deney ve kontrol gruplarının şarkı söyleme becerilerini değerlendirmeleri karşılaştırılarak pearson korelasyon katsayısına bakılmıştır. Korelasyon katsayısı, iki değişken arasındaki ilişkinin miktarını bulup yorumlamak amacıyla kullanılır (Büyüköztürk, 2004, s.31; Can 2017, s. 396). Bu araştırmada, iki puanlayıcı arasındaki yüksek korelasyon iki puanlayıcı arasındaki uyum miktarını göstermektedir. Şarkı Söyleme Becerisine Yönelik Gözlem Formu'ndan elde edilen verilerin güvenirliğinin incelenmesi amaciyla Cronbach Alpha katsayısı hesaplanıp yorumlanmıştır.

Tablo 5

Şarkı söyleme becerisine yönelik gözlem formu güvenirlik bulguları

\begin{tabular}{ccc}
\hline & $\mathbf{N}$ & Cronbach Alpha Katsayisı \\
\hline Ön Test & 16 & 0.835 \\
Son Test & 16 & 0.924 \\
\hline
\end{tabular}

Tablo 5 incelendiğinde, Şarkı Söyleme Becerisine Yönelik Gözlem Formu'nun ön test uygulamasından hesaplanan Cronbach Alfa katsayısının 0.835 ve son test uygulamasından hesaplanan Cronbach Alfa katsayısının 0.924 bulunduğu görülmektedir. Bulunan bu güvenirlik katsayılarının yüksek düzeyde güvenilir olduğu söylenebilir (Özdamar, 2004).

Tablo 6

Puanlayıcıların öntest ve sontest puanlamaları arasındaki korelasyon tablosu

\begin{tabular}{cccc}
\hline & $\mathbf{N}=\mathbf{2 5}$ & 2.Puanlayıcı Öntest & 2.Puanlayıcı Sontest \\
\hline 1.Puanlayıcı Öntest & & Korelasyon Katsayıs1 & $.921^{* *}$ \\
& & $\mathrm{p}$ & .000 \\
1.Puanlayıcı Sontest & Korelasyon Katsayıs1 & $.907^{* *}$ \\
& & $\mathrm{p}$ & .000 \\
\hline
\end{tabular}

Tablo 6 incelendiğinde, araştırmadaki iki ses eğitmeninin öğrencilerin şarkı söyleme becerilerini değerlendirmeleri arasındaki uyumun incelenmesi için yapılan pearson korelasyon katsayısının hesaplandığı ve iki ses eğitmeninin öntest değerlendirmeleri arasında pozitif yönlü yüksek düzeyde bir ilişki $(\mathrm{r}=.921, \mathrm{p}<.01)$, yine sontest değerlendirmeleri arasında pozitif yönlü yüksek düzeyde bir ilişki $(r=.907, p<.01)$ olduğu görülmektedir. Bu sonuçlara göre, iki ses eğitmeni arasında yüksek düzeyde pozitif ve anlamlı bir ilişkinin yani uyumun olduğu söylenebilir. Büyüköztürk'e (2004) göre, korelasyon katsayısının 1.00 olması, mükemmel pozitif bir ilişkiyi, -1.00 olması mükemmel negatif bir ilişkiyi, 0.00 olması, ilişkinin olmadığını gösterir. Korelasyon katsayısının büyüklük bakımından yorumlanmasında üzerinde tam olarak ortak görüşün paylaşıldığı aralıklar bulunmamakla birlikte, şu sınırlar sıklıkla kullanılabilir: Korelasyon katsayısının mutlak değer olarak 0.70-1.00 arasında olması, yüksek; 0.70-0.30 arasında olması ise düşük düzeyde bir ilişki olarak tanımlanabilir (s. 32).

Tablo 7

Öntest ve sontest puanlarının normallik incelemesi

\begin{tabular}{|c|c|c|c|}
\hline & & Ön Test Puanları & Son Test Puanları \\
\hline \multirow{5}{*}{ Deney Grubu } & $\mathrm{N}$ & 5 & 5 \\
\hline & Ortalama & 51.000 & 66.200 \\
\hline & Medyan & 51.000 & 67.000 \\
\hline & Çarpıklık & 0.000 & -0.363 \\
\hline & Basıklık & 0.893 & -2.413 \\
\hline \multirow{5}{*}{ Kontrol Grubu } & $\mathrm{N}$ & 5 & 5 \\
\hline & Ortalama & 46.400 & 56.400 \\
\hline & Medyan & 45.000 & 57.000 \\
\hline & Çarpıklık & 1.740 & -0.607 \\
\hline & Basıklık & 3.275 & -0.440 \\
\hline
\end{tabular}

Tablo 7'deki betimsel istatistikler incelendiğinde, merkezi eğilim ölçülerini oluşturan aritmetik ortalama ve medyan (ortanca) değerlerinin deney ve kontrol grubunun her ikisinde de öntest ve son testlerde birbirine yakın değerler olduğu görülmektedir. Her bir form için ortalama, mod ve medyan değerlerinin birbirinden çok uzak olmadığı, dağılımların normal dağılımdan aşırı sapmadığını düşündürse de, gruplardaki kişi sayıları göz önüne alındığında ayrıca deney ve kontrol gruplarında öntest ve sontestlerin çarpıklık ve basıklık katsayıları incelendiğinde; dağılımın normal dağılımdan sapma gösterdiği görülmektedir. Kontrol grubunda öntest ve sontestlerin çarpıklık ve basıklık katsayıları incelendiğinde; basıklık ve çarpıklık katsayılarının normal dağılım sınırları $(-1,+1)$ içinde olmadığı görülmektedir. Bu da dağılımın normal dağılımdan uzaklaştığının ispatı niteliğindedir. Sonuç olarak kontrol grubu öntest ve son test puanlarının normal dağılım göstermediği, deney grubu 
öntest ve son test puanlarının ise normal dağılım gösterdiği görülmektedir. Bu sonuçlar ışığında, normal dağılım gösteren durumlarda ilişkili örneklemler t testi, normal dağılım göstermeyen durumlarda Mann Whitney U testi ve Wilcoxon İşaretli Sıralar testi kullanılması gerektiğine karar verilmiştir.

Müzik öğretmeni adaylarının şarkı söyleme becerileri dikkate alındığında, gerek deneysel çalışmanın başlangıcında deney ve kontrol gruplarının Şarkı Söyleme Becerisine Yönelik Gözlem Formu'ndan aldıkları öntest puanları arasında fark olup olmadığını kontrol etmek, gerekse yine deney ve kontrol gruplarının Şarkı Söyleme Becerisine Yönelik Gözlem Formu'ndan aldıkları son test puanları arasında fark olup olmadığını kontrol etmek amacıyla Mann Whitney U Testi uygulanmıştır. Mann Whitney U Testi, iki ilişkisiz örneklemden elde edilen puanların birbirlerinden anlamlı bir şekilde farklılık gösterip göstermediğini test etmek için kullanılmaktadır. Test için, bağımlı değişkenin en az sıralama ölçeğinde ve gözlemlerin birbirinden bağımsız olması gerekir. Bu test, ilişkisiz ölçümlerin söz konusu olduğu az denekli deneysel çalışmalarda sıklıkla kullanılır (Büyüköztürk, 2004, s. 149).

Kontrol grubunun Şarkı Söyleme Becerisine Yönelik Gözlem Formu'ndan aldıkları öntest ve sontest puanları arasında fark olup olmadığını kontrol etmek amacıyla Wilcoxon İşaretli Sıralar Testi uygulanmıştır. Wilcoxon İşaretli Sıralar Testi, bir örneklemden elde edilen iki ilişkili puanın birbirinden anlamlı bir şekilde farklılaşıp farklılaşmadığını test etmek amacıyla kullanılmaktadır. Az denekli yürütülen gruplar içi araştırmalarda sıklıkla kullanılır. Deneklerin fark puanlarının normal dağılım göstermediği durumlarda ilişkili örneklemler t testi yerine tercih edilir (Büyüköztürk, 2004, s. 156). Deney grubunun Şark1 Söyleme Becerisine Yönelik Gözlem Formu'ndan aldıkları öntest ve sontest puanları arasında fark olup olmadığını kontrol etmek amacıyla İlişkili Örneklemler T Testi uygulanmıştır. İlişkili örneklemler T Testi, bir örneklemden elde edilen iki ilişkili puan arasında farklılık olup olmadığını test etmek amacıyla kullanılmaktadır. Deneklerin fark puanlarının normal dağılım gösterdiği durumlarda kullanılır (Büyüköztürk, 2004, s. 63). Araştırmada ayrıca, öntest ve sontest maddeleri için ayrı ayrı tek tek deney ve kontrol gruplarına göre ki- kare analizi uygulanmıştır. Bu analizle, deney ve kontrol grubunun madde bazında birbirlerinden ne derece farklılaştığı görülmek istenmektedir. Burada ki-kare testi uygulanmasının nedeni, deney ve kontrol şeklinde 2 gruptan oluşan bir kategorik değiş̧kene göre, 1, 2, 3, 4 ve 5 şeklinde 5 kategorili bir puanlamanın istatistiksel olarak anlamlı düzeyde farklılaşıp farklılaşmadığının incelenmesidir. Ki-kare testi, kategorik bir değişkenin düzeylerinde bulunan bireylerin yine başka bir kategorik değişkenin boyutlarına göre farklılık gösterip göstermediğini test etmek amacıyla kullanılmaktadır. Biri sınıflamalı diğeri sıralamalı iki kategorik değişkenin, değişken düzeylerine göre farklılaşıp farklılaşmadığını test etmek amacıyla uygulanır (Büyüköztürk, 2004, s. 142).

\section{Bulgular}

Müzik öğretmeni adaylarının şarkı söyleme becerileri dikkate alındığında, deneysel çalışmanın başlangıcında deney ve kontrol gruplarının Şarkı Söyleme Becerisine Yönelik Gözlem Formu'ndan aldıkları ön test puanlarının farklılık gösterip göstermediğini belirlemek amacıyla yapılan Mann Whitney U Testi sonuçları Tablo 8'de sunulmuştur.

Tablo 8

Deney ve kontrol grubu ön test puanlarının fark analizi

\begin{tabular}{ccccccc}
\hline & Grup & $\mathbf{N}$ & Sira ortalaması & Sira toplamı & U & p \\
\hline \multirow{3}{*}{ Öntest } & Kontrol & 5 & 4.00 & 20.00 & 35.00 & 5.000 \\
& Deney & 5 & 7.00 & 20.00 & .117 \\
& Toplam & 10 & 4.00 & & \\
\hline
\end{tabular}

Tablo 8'e göre, müzik öğretmeni adaylarının şarkı söyleme becerileri dikkate alındığında, deneysel çalışmanın başlangıcında deney ve kontrol gruplarının Şarkı Söyleme Becerisine Yönelik Gözlem Formu'ndan aldıkları ön test puanları arasında istatistiksel olarak anlamlı bir farklılık olmadığı görülmektedir $(U=5.00, p>0.05)$.

Müzik öğretmeni adaylarının şarkı söyleme becerileri dikkate alındığında, deneysel çalışmanın sonunda deney ve kontrol gruplarının Şarkı Söyleme Becerisine Yönelik Gözlem Formu'ndan aldıkları son test puanlarının farklılık gösterip göstermediğini belirlemek amacıyla yapılan Mann Whitney U Testi sonuçları Tablo 9'da sunulmuştur.

Tablo 9

Deney ve kontrol grubu son test puanlarının fark analizi

\begin{tabular}{ccccccc}
\hline & Grup & $\mathrm{N}$ & Sira ortalamas1 & Sira toplami & $\mathrm{U}$ \\
\hline \multirow{3}{*}{ Öntest } & Kontrol & 5 & 3.00 & 15.00 & $\mathrm{p}$ \\
& Deney & 5 & 8.00 & 40.00 & .000 & .009 \\
& Toplam & 10 & 3.00 & 15.00 & \\
\hline
\end{tabular}

Tablo 9'a göre, müzik öğretmeni adaylarının şarkı söyleme becerileri dikkate alındığında, deneysel çalışmanın sonunda, deney ve kontrol gruplarının Şarkı Söyleme Becerisine Yönelik Gözlem Formu'ndan aldıkları son test 
puanları arasında istatistiksel olarak anlamlı bir farklılık olduğu görülmektedir $(U=0.00, p<0.05)$. Ortaya çıkan bu fark incelendiğinde, deney grubundaki müzik öğretmeni adaylarının Şarkı Söyleme Becerisine Yönelik Gözlem Formu'ndan aldıkları son test puanları ortalamalarının kontrol grubundaki adaylardan daha yüksek olduğu görülmektedir. Bu sonuç, sözel imgelerin müzik öğretmeni adaylarının şarkı söyleme becerilerinin gelişmesi üzerinde anlamlı düzeyde etkili olduğunu ortaya koymaktadır. Büyüköztürk’e (2004, s. 152) göre de, analiz sonucu elde edilen p değeri 0.05 'den küçük ise, yapılan deneysel çalışmanın anlamlı düzeyde fark yarattığı söylenebilir.

Kontrol grubundaki müzik öğretmeni adaylarının şarkı söyleme becerileri dikkate alındığında, Şarkı Söyleme Becerisine Yönelik Gözlem Formu'ndan aldıkları öntest ve son test puanlarının farklılık gösterip göstermediğini belirlemek amacıyla yapılan Wilcoxon İşaretli Sıralar Testi sonuçları Tablo 10’da sunulmuştur.

Tablo 10

Kontrol grubunun ön test ve son test puanlarının fark analizi

\begin{tabular}{lccccc}
\hline & & N & Sıra ortalaması & Sıra toplamı & Z \\
\hline \multirow{3}{*}{ Kontrol Grubu } & Negatif Sıralar & $0^{\mathrm{b}}$ & .00 & .00 & $\mathbf{p}$ \\
& Pozitif Siralar & $5^{\mathrm{c}}$ & 3.00 & 15.00 & $-2.032^{\mathrm{c}}$ \\
& Eş Sıralar & $0^{\mathrm{d}}$ & & & .042 \\
& Toplam & 5 & & & \\
\hline
\end{tabular}

c. sontest_top_puanlayıc1>öntest_top_puanlayıc1

Tablo 10’a göre, kontrol grubundaki müzik öğretmeni adaylarının şarkı söyleme becerileri dikkate alındığında, Şarkı Söyleme Becerisine Yönelik Gözlem Formu'ndan aldıkları öntest ve sontest puanları arasında istatistiksel olarak anlamlı bir farklılık olduğu görülmektedir $\left(Z=-2,032^{c}, p<0.05\right)$. Bu fark pozitif siralar lehinedir. Kontrol grubundaki müzik öğretmeni adaylarının sontest puan ortalamalarının $(\bar{X}=56.400)$ ön test puan ortalamalarından $(\bar{X}=46.400)$ yüksek olduğu görülmektedir.

Deney grubundaki müzik öğretmeni adaylarının şarkı söyleme becerileri dikkate alındığında, Şarkı Söyleme Becerisine Yönelik Gözlem Formu'ndan aldıkları öntest ve son test puanlarının farklılık gösterip göstermediğini belirlemek amacıyla yapılan İlişkili Örneklemler T Testi sonuçları Tablo 11'de sunulmuştur.

Tablo 11

Deney grubunun ön test ve son test puanlarının fark analizi

\begin{tabular}{cccccc}
\hline Ölçüm & $\mathbf{N}$ & $\overline{\boldsymbol{X}}$ & $\mathbf{S}$ & $\mathbf{s d}$ & $\mathbf{p}$ \\
\hline Ön Test & 5 & 51.200 & 4.764 & 4 & $\mathbf{1}$ \\
Son Test & 5 & 68.600 & 2.073 & 4 & \multirow{2}{*}{0.000} \\
\hline
\end{tabular}

Tablo 11'e göre, deney grubundaki müzik öğretmeni adaylarının şarkı söyleme becerileri dikkate alındığında, Şarkı Söyleme Becerisine Yönelik Gözlem Formu'ndan aldıkları öntest ve sontest puanları arasında istatistiksel olarak anlamlı bir farklılık olduğu $(\mathrm{t}=-12,123, \mathrm{p}<0.05)$ ve deney grubundaki müzik öğretmeni adaylarının son test puan ortalamalarının $(\bar{X}=68.600)$ ön test puan ortalamalarından $(\bar{X}=51.200)$ yüksek olduğu görülmektedir.

Deneysel desen ile ilgili yapılan 4 fark analizi bir arada değerlendirildiğinde, öntest aşamasında deney ve kontrol grupları arasında fark çıkmaması, bu iki grubun ölçülen özellik bakımından denk olduğunu göstermektedir. Deney ve kontrol gruplarının her ikisinin öntest ve sontest puanları arasında fark olması, bu iki grubun deneysel süreç içerisinde ölçülen özellik bakımından gelişim gösterdiği anlamına gelmektedir. Fakat son testler arasında farklar incelendiğinde, deney grubunun ölçülen özellik bakımından kontrol grubundan daha iyi olduğu görülmektedir. Bu durum, müzik öğretmeni adaylarına verilen deneysel eğitimin etkililiğini göstermektedir. Kontrol grubunun öntest ve sontest puanları arasındaki farkın nedeninin, deneysel çalışmanın dışında alınan genel eğitimin de öğrencilerin gelişimine katkı sağlamasından kaynaklı olduğu söylenebilir.

Tablo 12

Öntest maddelerinin kontrol ve deney grupları ki-kare sonuçları

\begin{tabular}{|c|c|c|c|c|c|c|c|c|}
\hline \multirow{2}{*}{ Madde } & \multirow{2}{*}{ Grup } & & \multicolumn{5}{|c|}{ Puanlama } & \multirow{2}{*}{ Ki-Kare (p) } \\
\hline & & & 1 & 2 & 3 & 4 & 5 & \\
\hline \multirow{4}{*}{ 1.Madde } & \multirow{2}{*}{ Kontrol } & $\mathrm{P}$ & 0 & 0 & 1 & 4 & 0 & \\
\hline & & $\%$ & 0 & 0 & 20.0 & 80.0 & 0 & 0.000 \\
\hline & \multirow[b]{2}{*}{ Deney } & $\mathrm{P}$ & 0 & 0 & 1 & 4 & 0 & 1.000 \\
\hline & & $\%$ & 0 & 0 & 20.0 & 80.0 & 0 & \\
\hline \multirow{4}{*}{ 2.Madde } & \multirow{2}{*}{ Kontrol } & $\mathrm{P}$ & 0 & 2 & 2 & 1 & 0 & \\
\hline & & $\%$ & 0 & 40.0 & 40.0 & 20.0 & 0 & 4.133 \\
\hline & \multirow[t]{2}{*}{ Deney } & $\mathrm{P}$ & 0 & 0 & 1 & 4 & 0 & 0.127 \\
\hline & & $\%$ & 0 & 0 & 20.0 & 80.0 & 0 & \\
\hline
\end{tabular}


Tablo 12'nin devamı

\begin{tabular}{|c|c|c|c|c|c|c|c|c|}
\hline \multirow{2}{*}{ Madde } & \multirow{2}{*}{ Grup } & \multicolumn{6}{|c|}{ Puanlama } & \multirow{2}{*}{ Ki-Kare (p) } \\
\hline & & & 1 & 2 & 3 & 4 & 5 & \\
\hline \multirow{4}{*}{ 3.Madde } & Kontrol & $\mathrm{P}$ & 0 & 4 & 1 & 0 & 0 & \\
\hline & & $\%$ & 0 & 80.0 & 20.0 & 0 & 0 & 4.133 \\
\hline & Deney & $\mathrm{P}$ & 0 & 1 & 2 & 2 & 0 & 0.127 \\
\hline & & $\%$ & 0 & 20.0 & 40.0 & 40.0 & 0 & \\
\hline \multirow{4}{*}{ 4.Madde } & Kontrol & $\mathrm{P}$ & 0 & 2 & 3 & 0 & 0 & \\
\hline & & $\%$ & 0 & 40.0 & 60.0 & 0 & 0 & 4.333 \\
\hline & Deney & $\mathrm{P}$ & 0 & 1 & 1 & 3 & 0 & 0.115 \\
\hline & & $\%$ & 0 & 20.0 & 20.0 & 60.0 & 0 & \\
\hline \multirow{4}{*}{ 5.Madde } & Kontrol & $\mathrm{P}$ & 0 & 4 & 0 & 1 & 0 & \\
\hline & & $\%$ & 0 & 80.0 & 0 & 20.0 & 0 & 10.000 \\
\hline & Deney & $\mathrm{P}$ & 0 & 0 & 5 & 0 & 0 & $0.007 *$ \\
\hline & & $\%$ & 0 & 0 & 100.0 & 0 & 0 & \\
\hline \multirow{4}{*}{ 6.Madde } & Kontrol & $\mathrm{P}$ & 0 & 3 & 1 & 1 & 0 & \\
\hline & & $\%$ & 0 & 60.0 & 20.0 & 20.0 & 0 & 1.667 \\
\hline & Deney & $\mathrm{P}$ & 0 & 1 & 2 & 2 & 0 & 0.435 \\
\hline & & $\%$ & 0 & 20.0 & 40.0 & 40.0 & 0 & \\
\hline \multirow{4}{*}{ 7.Madde } & Kontrol & $\mathrm{P}$ & 0 & 0 & 1 & 3 & 1 & \\
\hline & & $\%$ & 0 & 0 & 20.0 & 60.0 & 20.0 & 1.333 \\
\hline & Deney & $\mathrm{P}$ & 0 & 0 & 0 & 3 & 2 & 0.513 \\
\hline & & $\%$ & 0 & 0 & 0 & 60.0 & 40.0 & \\
\hline \multirow{4}{*}{ 8.Madde } & Kontrol & $P$ & 0 & 0 & 0 & 4 & 1 & \\
\hline & & $\%$ & 0 & 0 & 0 & 80.0 & 20.0 & 0.476 \\
\hline & Deney & $\mathrm{P}$ & 0 & 0 & 0 & 3 & 2 & 0.500 \\
\hline & & $\%$ & 0 & 0 & 0 & 60.0 & 40.0 & \\
\hline \multirow{4}{*}{ 9.Madde } & Kontrol & $\mathrm{P}$ & 0 & 1 & 4 & 0 & 0 & \\
\hline & & $\%$ & 0 & 20.0 & 80.0 & 0 & 0 & 1.111 \\
\hline & Deney & $\mathrm{P}$ & 0 & 0 & 5 & 0 & 0 & 0.500 \\
\hline & & $\%$ & 0 & 0 & 100.0 & 0 & 0 & \\
\hline \multirow{4}{*}{ 10.Madde } & Kontrol & $\mathrm{P}$ & 0 & 1 & 0 & 4 & 0 & \\
\hline & & $\%$ & 0 & 20.0 & 0 & 80.0 & 0 & 3.143 \\
\hline & Deney & $\mathrm{P}$ & 0 & 0 & 2 & 3 & 0 & 0.208 \\
\hline & & $\%$ & 0 & 0 & 40.0 & 60.0 & 0 & \\
\hline \multirow{4}{*}{ 11.Madde } & Kontrol & $\mathrm{P}$ & 0 & 5 & 0 & 0 & 0 & \\
\hline & & $\%$ & 0 & 100.0 & 0 & 0 & 0 & 2.500 \\
\hline & Deney & $\mathrm{P}$ & 0 & 3 & 2 & 0 & 0 & 0.222 \\
\hline & & $\%$ & 0 & 60.0 & 40.0 & 0 & 0 & \\
\hline \multirow{4}{*}{ 12.Madde } & Kontrol & $\mathrm{P}$ & 0 & 4 & 1 & 0 & 0 & \\
\hline & & $\%$ & 0 & 80.0 & 20.0 & 0 & 0 & 0.000 \\
\hline & Deney & $\mathrm{P}$ & 0 & 4 & 1 & 0 & 0 & 1.00 \\
\hline & & $\%$ & 0 & 80.0 & 20.0 & 0 & 0 & \\
\hline \multirow{4}{*}{ 13.Madde } & Kontrol & $\mathrm{P}$ & 0 & 0 & 1 & 4 & 0 & \\
\hline & & $\%$ & 0 & 0 & 20.0 & 80.0 & 0 & 2.000 \\
\hline & Deney & $\mathrm{P}$ & 0 & 0 & 0 & 4 & 1 & 0.368 \\
\hline & & $\%$ & 0 & 0 & 0 & 80.0 & 20.0 & \\
\hline \multirow{4}{*}{ 14.Madde } & Kontrol & $\mathrm{P}$ & 0 & 3 & 1 & 1 & 0 & \\
\hline & & $\%$ & 0 & 60.0 & 20.0 & 20.0 & 0 & 2.500 \\
\hline & Deney & $\mathrm{P}$ & 0 & 5 & 0 & 0 & 0 & 0.287 \\
\hline & & $\%$ & 0 & 100.0 & 0 & 0 & 0 & \\
\hline & Kontrol & $\mathrm{P}$ & 0 & 4 & 0 & 1 & 0 & \\
\hline & & $\%$ & 0 & 80.0 & 0 & 20.0 & 0 & 3.143 \\
\hline 15.Madde & Deney & $\mathrm{P}$ & 0 & 3 & 2 & 0 & 0 & 0.208 \\
\hline & & $\%$ & 0 & 60.0 & 40.0 & 0 & 0 & \\
\hline & Kontrol & $\mathrm{P}$ & 0 & 4 & 1 & 0 & 0 & \\
\hline & & $\%$ & 0 & 80.0 & 20.0 & 0 & 0 & 1.111 \\
\hline I6.Madde & Deney & $\mathrm{P}$ & 0 & 5 & 0 & 0 & 0 & 0.500 \\
\hline & & $\%$ & 0 & 100.0 & 0 & 0 & 0 & \\
\hline
\end{tabular}

Tablo 12'deki sonuçlara göre, deneysel çalışmanın başında deney ve kontrol gruplarının Şarkı Söyleme Becerisine Yönelik Gözlem Formu'ndaki maddelerden aldıkları puanlar karşılaştırıldığında, 15 maddenin ki-kare değerlerinin 0.05 değerinden büyük olduğu yani maddelerden alınan puanların deney ve kontrol gruplarında istatistiksel olarak anlamlı bir farklılık göstermediği görülmektedir. Madde 5'de ise deney ve kontrol gruplarının o maddeden aldıkları puanların istatistiksel olarak anlamlı bir şekilde farklılaştığı görülmektedir $(\mathrm{p}<0.05)$. Madde 5 'den ("Doğru vokal pozisyonda söyler.") kontrol grubundaki 4 kişinin 2 puan, 1 kişinin 4 puan aldığı ve deney grubundaki 5 kişinin 3 puan aldı̆̆ görülmektedir. 


\section{Tablo 13}

Sontest maddelerinin kontrol ve deney grupları ki-kare sonuçları

\begin{tabular}{|c|c|c|c|c|c|c|c|c|}
\hline \multirow{2}{*}{ Madde } & \multirow{2}{*}{ Grup } & & \multicolumn{5}{|c|}{ Puanlama } & \multirow{2}{*}{ Ki-Kare (p) } \\
\hline & & & 1 & 2 & 3 & 4 & 5 & \\
\hline \multirow{4}{*}{ 1.Madde } & \multirow{2}{*}{ Kontrol } & $\mathrm{P}$ & 0 & 0 & 0 & 5 & 0 & - \\
\hline & & $\%$ & 0 & 0 & 0 & 100.0 & 0 & \\
\hline & \multirow{2}{*}{ Deney } & $\mathrm{P}$ & 0 & 0 & 0 & 5 & 0 & \\
\hline & & $\%$ & 0 & 0 & 0 & 100 & 0 & \\
\hline \multirow{4}{*}{ 2.Madde } & \multirow{2}{*}{ Kontrol } & $\mathrm{P}$ & 0 & 0 & 0 & 5 & 0 & - \\
\hline & & $\%$ & 0 & 0 & 0 & 100.0 & 0 & \\
\hline & \multirow{2}{*}{ Deney } & $\mathrm{P}$ & 0 & 0 & 0 & 5 & 0 & \\
\hline & & $\%$ & 0 & 0 & 0 & 100 & 0 & \\
\hline \multirow{4}{*}{ 3.Madde } & \multirow[t]{2}{*}{ Kontrol } & $\mathrm{P}$ & 0 & 0 & 3 & 2 & 0 & \\
\hline & & $\%$ & 0 & 0 & 60.0 & 40.0 & 0 & 4.667 \\
\hline & Deney & $\mathrm{P}$ & 0 & 0 & 0 & 4 & 1 & 0.097 \\
\hline & & $\%$ & 0 & 0 & 0 & 80.0 & 20.0 & \\
\hline & Kontrol & $\mathrm{P}$ & 0 & 1 & 4 & 0 & 0 & \\
\hline & & $\%$ & 0 & 20.0 & 80.0 & 0 & 0 & 6.800 \\
\hline 4.Madde & Deney & $\mathrm{P}$ & 0 & 0 & 1 & 4 & 0 & $0.033^{*}$ \\
\hline & & $\%$ & 0 & 0 & 20.0 & 80.0 & 0 & \\
\hline & Kontrol & $\mathrm{P}$ & 0 & 0 & 3 & 2 & 0 & \\
\hline & & $\%$ & 0 & 0 & 60.0 & 40.0 & 0 & 4.286 \\
\hline 5.Madde & Deney & $P$ & 0 & 0 & 0 & 5 & 0 & 0.083 \\
\hline & & $\%$ & 0 & 0 & 0 & 100.0 & 0 & \\
\hline & Kontrol & $\mathrm{P}$ & 0 & 0 & 4 & 1 & 0 & \\
\hline & & $\%$ & 0 & 0 & 80.0 & 20.0 & 0 & 6.667 \\
\hline 6.Madde & Deney & $\mathrm{P}$ & 0 & 0 & 0 & 5 & 0 & $0.024 *$ \\
\hline & & $\%$ & 0 & 0 & 0 & 100.0 & 0 & \\
\hline & Kontrol & $\mathrm{P}$ & 0 & 0 & 0 & 0 & 5 & - \\
\hline & & $\%$ & 0 & 0 & 0 & 0 & 100.0 & \\
\hline 7.Madde & Deney & $\mathrm{P}$ & 0 & 0 & 0 & 0 & 5 & \\
\hline & & $\%$ & 0 & 0 & 0 & 0 & 100.0 & \\
\hline & Kontrol & $\mathrm{P}$ & 0 & 0 & 0 & 1 & 4 & \\
\hline & & $\%$ & 0 & 0 & 0 & 20.0 & 80.0 & 0.000 \\
\hline 8.Madde & Deney & $\mathrm{P}$ & 0 & 0 & 0 & 1 & 4 & 1.000 \\
\hline & & $\%$ & 0 & 0 & 0 & 20.0 & 80.0 & \\
\hline & Kontrol & $\mathrm{P}$ & 0 & 0 & 2 & 3 & 0 & \\
\hline Q Madde & & $\%$ & 0 & 0 & 40.0 & 60.0 & 0 & 3.143 \\
\hline 9.Madde & Deney & $P$ & 0 & 0 & 0 & 4 & 1 & 0.208 \\
\hline & & $\%$ & 0 & 0 & 0 & 80.0 & 20.0 & \\
\hline & Kontrol & $P$ & 0 & 0 & 2 & 3 & 0 & \\
\hline & & $\%$ & 0 & 0 & 40.0 & 60.0 & 0 & 7.000 \\
\hline 10.Madde & Deney & $\mathrm{P}$ & 0 & 0 & 0 & 1 & 4 & $0.030 *$ \\
\hline & & $\%$ & 0 & 0 & 0 & 20.0 & 80.0 & \\
\hline & Kontrol & $\mathrm{P}$ & 0 & 1 & 3 & 1 & 0 & \\
\hline & & $\%$ & 0 & 20.0 & 60.0 & 20.0 & 0 & 3.800 \\
\hline 11.Madde & Deney & $\mathrm{P}$ & 0 & 0 & 1 & 4 & 0 & 0.150 \\
\hline & & $\%$ & 0 & 0 & 20.0 & 80.0 & 0 & \\
\hline & Kontrol & $\mathrm{P}$ & 0 & 2 & 2 & 1 & 0 & \\
\hline & & $\%$ & 0 & 40.0 & 40.0 & 20.0 & 0 & 4.133 \\
\hline 12.Madde & Deney & $P$ & 0 & 0 & 1 & 4 & 0 & 0.127 \\
\hline & & $\%$ & 0 & 0 & 20.0 & 80.0 & 0 & \\
\hline & Kontrol & $P$ & 0 & 0 & 0 & 3 & 2 & \\
\hline 13 Modd & & $\%$ & 0 & 0 & 0 & 60.0 & 40.0 & 4.286 \\
\hline 13.Madde & Deney & $P$ & 0 & 0 & 0 & 0 & 5 & 0.083 \\
\hline & & $\%$ & 0 & 0 & 0 & 0 & 100.0 & \\
\hline & Kontrol & $\mathrm{P}$ & 0 & 1 & 4 & 0 & 0 & \\
\hline & & $\%$ & 0 & 20.0 & 80.0 & 0 & 0 & 4.667 \\
\hline 14.Madde & Deney & $\mathrm{P}$ & 0 & 0 & 2 & 3 & 0 & 0.097 \\
\hline & & $\%$ & 0 & 0 & 40.0 & 60.0 & 0 & \\
\hline & Kontrol & $P$ & 0 & 2 & 2 & 1 & 0 & \\
\hline & & $\%$ & 0 & 40.0 & 40.0 & 20.0 & 0 & 3.000 \\
\hline 15.Madde & Deney & $\mathrm{P}$ & 0 & 0 & 2 & 3 & 0 & 0.223 \\
\hline & & $\%$ & 0 & 0 & 40.0 & 60.0 & 0 & \\
\hline & Kontrol & $P$ & 0 & 2 & 2 & 1 & 0 & \\
\hline & & $\%$ & 0 & 40.0 & 40.0 & 20.0 & 0 & 3.000 \\
\hline 16.Madde & Deney & $\mathrm{P}$ & 0 & 0 & 2 & 3 & 0 & 0.223 \\
\hline & & $\%$ & 0 & 0 & 40.0 & 60.0 & 0 & \\
\hline
\end{tabular}

Tablo 13'e göre, deneysel çalışmanın sonunda deney ve kontrol gruplarının Şarkı Söyleme Becerisine Yönelik Gözlem Formu'ndaki maddelerden aldıkları puanlar karşılaştırıldığında, 13 maddenin ki-kare değerlerinin 0.05 değerinden büyük olduğu yani maddelerden alınan puanların deney ve kontrol gruplarında istatistiksel olarak anlamlı bir farklılık göstermediği görülmektedir. Madde 4'de ise deney ve kontrol gruplarının o maddeden 
aldıkları puanların istatistiksel olarak anlamlı bir şekilde farklılaştı̆̆ı görülmektedir (p<0.05). Madde 4'den ("Sesi rezonans bölgesine alır.”) kontrol grubundaki 1 kişinin 2 puan, 4 kişinin 3 puan aldığ 1 ve deney grubundaki 1 kişinin 3 puan, 4 kişinin 4 puan aldı ğ 1 görülmektedir. Madde 6'da ise deney ve kontrol gruplarının o maddeden aldıkları puanların istatistiksel olarak anlamlı bir şekilde farklılaştı̆ğ görülmektedir $(\mathrm{p}<0.05)$. Madde 6'dan ("Register geçişlerini doğru yapar.”) kontrol grubundaki 4 kişinin 3 puan, 1 kişinin 4 puan aldığ 1 ve deney grubundaki 5 kişinin 4 puan aldığ görülmektedir. Madde 10'da ise deney ve kontrol gruplarının o maddeden aldıkları puanların istatistiksel olarak anlamlı bir şekilde farklılaştığı görülmektedir $(\mathrm{p}<0.05)$. Madde 10'dan ("Şarkı sözlerini doğru telaffuz eder.”) kontrol grubundaki 2 kişinin 3 puan, 3 kişinin 4 puan aldığ 1 ve deney grubundaki 1 kişinin 4 puan, 4 kişinin 5 puan aldığı görülmektedir.

\section{Sonuç ve Öneriler}

Sözel imgelerin müzik öğretmeni adaylarının şarkı söyleme becerileri üzerindeki etkisini belirlemek amacıyla yapılan bu araştırmada, 12 hafta boyunca deney grubuna uygulanan sözel imgelerle yapılan ses eğitiminin müzik öğretmeni adaylarının şarkı söyleme becerileri üzerinde istatistiksel olarak anlamlı düzeyde etkisi olduğu sonucuna ulaşılmıştır. Bulgular, araştırmanın başlangıcında, deney ve kontrol grubunun denk olduğu ve hem deney grubunun hem de kontrol grubunun eğitim öncesi ve eğitim sonrası şarkı söyleme becerileri arasında fark olduğu yönündedir. Deney grubunda yer alan müzik öğretmeni adaylarının eğitim öncesi ve sonrası şarkı söyleme becerilerinde istatistiksel olarak anlamlı bulunan fark, verilen 12 haftalık ses eğitiminin müzik öğretmeni adayları üzerindeki etkililiğinin ispatı niteliğindedir. Araştırma sonucunda, kontrol grubunun da şarkı söyleme becerilerinin geliştiği gözlemlenmiştir. Bu değişimin nedeni ise kontrol grubunda yer alan müzik öğretmeni adaylarının rutin eğitim-öğretim programlarına devam ederek kendilerini geliştirmeleri şeklinde açıklanabilir. Sonuç olarak, müzik öğretmeni adaylarının şarkı söyleme becerilerinin geliştirilmesinde sözel imgelerin yerinin oldukça önemli olduğu sonucuna varılabilir

Araştırmada, doğru, güzel ve etkili şarkı söyleme becerisi, bütünsel bir yaklaşım içinde ele alınmış ve bu nedenle toplam puanlar üzerinden analiz yapılmıştır. Güzel şarkı söylemede temel olan, postür, solunum, fonasyon, rezonans ve artikülasyon süreçleri bir bütün olduğu için, bu süreçlerin herhangi birinde yaşanan olumsuzluk diğerlerini de etkilemekte ve sonuç olarak sese yansımaktadır. Bu bağlamda, doğru, rahat ve güzel şarkı söyleme becerisi, bu süreçler birbirleri ile koordineli olduğunda gerçekleşmektedir. Dolayısıyla, doğru solunum tekniği için doğru postür, sağlıklı ve güzel ses üretimi için doğru solunum temeldir. Şarkı söyleme performansındaki başarı, tüm süreçlerin verimli ve koordineli çalıştığının göstergesi olduğundan, bu araştırma sonucuna göre, ses eğitiminde sözel imgelerin kullanılmasının tüm süreçleri olumlu yönde etkilediği düşünülebilir.

Araştırma sonucunda genel bir değerlendirme yapmak gerekirse, müzik öğretmeni yetiştirme kapsamında yer alan Ses Eğitimi dersinde, öğretmen adaylarının en temel ve doğal iletişim ve müzikal ifade aracı olan sesleri doğal haliyle korunarak, şarkı söyleme becerilerinin geliştirilmesi amaçlanmaktadır. Bu amacın gerçekleștirilmesi onlara sunulacak nitelikli eğitim anlayışı ile sağlanabilir. Dolayısıyla eğitim sürecinde kullanılacak etkili ve verimli öğretim yöntemlerinin seçilmesi önemlidir. Bu bağlamda, ses eğitmenleri Ses Eğitimi derslerinde sözel imgeler yoluyla, postür, solunum, ses üretimi, rezonans ve artikülasyon gibi sesin oluşmasında temel olan fiziksel süreçlere odaklanarak, öğrencilerin şarkı söyleme becerilerini yüksek düzeyde daha da sağlamlaştırıp güçlendirebilirler. Ses eğitiminde sözel imgelerin bir öğretim yöntemi olarak kullanılması yoluyla şarkı söyleme becerilerinin geliştirilmesi, öğrencilere uzun yıllar sağlıklı bir sesle şarkı söyleme olanağı sağlayacağı gibi, öğretmen-öğrenci iletişiminin ve eğitim sürecinin daha sağlıklı, verimli ve etkili olmasına katkıda bulunacaktır.

İçinde bulunduğumuz bilgi çağında, eğitim sürecinde rol oynayan özellikle iki faktör öne çıkmaktadır: Nitelikli eğitmenler ve çağdaş öğretim yöntemleri. Bu bağlamda, çağın gerekleri doğrultusunda, eğitmenlerin kendilerini ve kullandıkları öğretim yöntemlerini yenilemesi ve çeşitlendirmesi zorunludur. Clements'e (2008) göre, yirmi birinci yüzyılda öğretim yöntemleri hala değişkendir. Ses eğitimine yardımcı olmak için elektronik, spektrograf ve diğer makineleri kullanan eğitmenler olduğu gibi, bilimsel yaklaşımla öğrencilerin doğru bir tekniğ keşfetmelerine yardımcı olmaya çalışan eğitmenler de vardır. Ses biliminin yükselişi, bugünün pedagoguna ses mekanizmasının nasıl işlediğine dair daha doğru bir tanımlama yapmıştır. Bu açıklama, diğer yandan birçok öğretmenin imgelemden saf vokal bilime doğru uzaklaşmasına neden olmuştur. Bazı öğrenciler için bilimsel yaklaşım başarılı değildir. Bu nedenle, imgelem ve bilimsel yaklaşım arasındaki bağlantı yeteneği, pedagojik jenerasyonlar arasındaki uçurumu kapatacaktır. Ayrıca, yirmi birinci yüzyılda mesleğinde ilerleyebilecek pedagogların yaratılmasına da yardımcı olacaktır. Yirmi birinci yüzyılda farklı olan şey, tüm öğretmenlerin en rahat oldukları öğretim yöntemini geliştirmelerine olanak tanıyan çok sayıda bilgi ve kaynak olmasıdır.

"Müzisyen, imgeler dünyasında yaşar" diyen Seashore (1938) imgeyi, öğrenme için bir durum, gereklilik olarak tanımlarken, Overby (1990); “imgenin gücü, öğrenmeyi kolaylaştıran bir faktör olarak iş görür” demektedir (aktaran Wei, 2006, s. 1-2).

Son olarak, San'ın (1983) belirttiği gibi, sağlıklı, başarılı ve yaratıcı bir eğitim, bir anlamda bireyin tam ve eksiksiz yetişmesi için gerekli olan eğitim, akılcı ve nesnel eğitim ile imgelemin eğitimini dengeleyerek yapılırsa yararlı 
olur. Böyle bir eğitim almış olan birey, tüm zihinsel yetilerini, düşüncelerini, duyularını, imgelerini ve imgelemini etkileşim haline sokarak yaratıcı buluşlar yapabilir (aktaran Oskay, 2004, s. 36).

Araştırmanın sonucunda şunlar önerilebilir:

*Ülkemizde ulaşılabilindiği kadarıyla ses eğitimi alanında bu konuda bir çalışmaya rastlanamadığından, bu araştırmadan yola çıkarak yeni araştırmalar ve daha detaylı lisansüstü tez çalışmaları yapılabilir.

*Müzik öğretmeni adayları üzerinde, sözel imgelere dayalı aldıkları ses eğitimini uygulama okullarında ne kadar yansıtabildikleri konusunda araştırmalar yapılabilir.

*Ülkemizde, ses eğitmenlerinin sözel imgelerin kullanımına ilişkin görüşleri ve ses eğitimi derslerinde sözel imgelerin kullanılma sıklı̆̆ üzerine çalışmalar yapılabilir.

\section{Kaynakça}

Berger, J. (1995). Görme biçimleri. İstanbul: Metis Yayınları

Büyüköztürk, Ş. (2004). Sosyal bilimler için veri analizi el kitabı. Ankara: Pegem A Yayıncılık.

Can, A. (2017). Spss ile bilimsel araştırma sürecinde nicel veri analizi. Ankara: Pegem Akademi.

Clements, J. F. (2008). The use of imagery in teaching voice to the twenty-first century student (Doktora Tezi). Florida State University College of Music). Erişim adresi: https://search.proquest.com/pqdtglobal/results/ 880BE41AB726478CPQ/1?accountid=10527

Fields, V. A. (1972). How mind governs voice. The NATS Bulletin, 22(2), 2-10.

Freed, D. C. (2000). Imagery in early twentieth-century american vocal pedagogy. Journal of Singing, 56(4), 512 .

Hall, C. R. (2001). Imagery in sport and exercise. (2nd Edition). R.N. Singer ve H. A. Hausenblas, Ed.), Handbook of Research on Sport Psychology.(s. 538) içinde. New York: John Willy\& Sons.

Hemsley, T. (1998). Singing and imagination.: A human approach to a great musical tradition. Oxford: Oxford University Press.

Işıldak, R. S. (2008). Yaratmada ilk adım: imge ve imgelem. Necatibey Eğitim Fakültesi Elektronik Fen ve Matematik Eğitimi Dergisi (EFMED), 2(1), 64-69. Erişim adresi: http://www.nef.balikesir.edu.tr/ dergi/makaleler/yayinda/4/EFMED_FZE115.pdf

Kagen, S. (1960). On studying singing. Newyork: Dover Publications, Inc.

Keser, N. (2005). Sanat sözlüğü. Ankara: Ütopya Yayınevi.

Kırışoğlu, O. T. (2005). Sanatta ĕgitim: Görmek öğrenmek yaratmak. Ankara: Pegem A Yayıncılık.

Kızıldağ, E., \& Tiryaki, M. Ş. (2012). Sporda imgeleme envanterinin Türk sporcular için uyarlanması. Spor Bilimleri Dergisi, 23(1), 13-23. Erişim adresi: http://dergipark.ulakbim.gov.tr/sbd/article/view/5000092267/ 5000085742

McKinney, J. C. (1994). The diagnosis and correction of vocal faults: A manual for teachers of singing and for choir directors. USA: Nashville, Genevox Music Group.

Oskay, Y. (2004). Sanat eğitiminde imge ve imgenin yeri (Yüksek lisans tezi). YÖK tez veri tabanından erişildi (Tez No. 143845).

Overby, L. Y. (1990). The use of imagery by dance teachers - development and implementation of two research instruments. Journal of Physical Education Recreation and Dance, February, 24-27. doi: https://doi.org/10.1080/07303084.1990.10606437

Ömür, M. (2001). Sesin peşinde. İstanbul: Pan Yayıncılık.

Özdamar, K. (2004). Paket programlar ile istatistiksel veri analizi. Eskişehir: Kaan Kitabevi.

Read, H. (1963). Education through art. London: Faber and Faber

San, İ. (1983). Sanat eğitimi kuramlarl. Ankara: Tan Yayınları.

Seashore, C. E. (1938). Psychology of music. New York: McGraw-Hill.

Timuçin, A. (2000). Estetik. İstanbul: Bulut Yayınları 
Türk Dil Kurumu (TDK). (t.y.). Büyük Türkçe Sözlük. Erişim adresi: http://www.tdk.gov.tr/index.php?option= com_bts

Vennard, W. (1967). Singing: The mechanism and the technic. Newyork: Carl Fischer, Inc.

Wei, C. T. (2006). Role and efficacy of verbal imagery in the teaching of singing: case study and computer vocal analysis (Doktora Tezi). Erişim Adresi: https://search.proquest.com/pqdtglobal/results/981CFFC47E3A474 $\mathrm{BPQ} / 1$ ?accountid=10527

Winsel, R. (1966). The anatomy of voice: an illustrated manual of vocal training. New York: Exposition Press,

\section{Ek 1. Şarkı Söyleme Becerisine Yönelik Gözlem Formu}

\begin{tabular}{|c|c|c|c|c|c|c|}
\hline \multicolumn{7}{|l|}{$\begin{array}{l}\text { Öğrenci Adı: } \\
\text { Sınıfı: }\end{array}$} \\
\hline \multirow{2}{*}{ Hedefler } & \multirow{2}{*}{ Hedef Davranışlar } & \multicolumn{5}{|c|}{ Puan } \\
\hline & & 1 & 2 & 3 & 4 & 5 \\
\hline \multirow{6}{*}{$\begin{array}{l}\text { Tekniği doğru } \\
\text { kullanabilme }\end{array}$} & Doğru duruş pozisyonu alır. & & & & & \\
\hline & Solunumu kontrollü kullanır. & & & & & \\
\hline & Ses-soluk bağlantısını doğru kurar. & & & & & \\
\hline & Sesi rezonans bölgesine alır. & & & & & \\
\hline & Doğru vokal pozisyonda söyler. & & & & & \\
\hline & Register geçişlerini doğru yapar. & & & & & \\
\hline \multirow{4}{*}{$\begin{array}{l}\text { Şarkıyı doğru } \\
\text { söyleyebilme }\end{array}$} & Ritmik hata yapmadan söyler. & & & & & \\
\hline & Doğru entonasyonla söyler. & & & & & \\
\hline & Doğru artikülasyonla söyler. & & & & & \\
\hline & Şarkı sözlerini doğru telaffuz eder. & & & & & \\
\hline \multirow{2}{*}{$\begin{array}{l}\text { Şarkıyı stiline uygun } \\
\text { söyleyebilme }\end{array}$} & $\begin{array}{l}\text { Şarkıları dönem özelliklerine göre uygun } \\
\text { stilde söyler. }\end{array}$ & & & & & \\
\hline & Şarkıları türüne göre uygun stilde söyler. & & & & & \\
\hline $\begin{array}{l}\text { Eşlikle uyumlu } \\
\text { söyleyebilme }\end{array}$ & Şarkıyı eşlik çalgısıyla uyum içinde söyler. & & & & & \\
\hline \multirow{3}{*}{ Müzikal söyleyebilme } & $\begin{array}{l}\text { Şarkıda, anlatımın ifade edilmesine yönelik } \\
\text { nüansları doğru yapar. }\end{array}$ & & & & & \\
\hline & $\begin{array}{l}\text { Şarkıda, ezginin yansıttığı duyguyu } \\
\text { hissederek söyler. }\end{array}$ & & & & & \\
\hline & $\begin{array}{l}\text { Şarkı sözlerinin yansıttığı duyguyu } \\
\text { hissederek söyler. }\end{array}$ & & & & & \\
\hline
\end{tabular}

